\title{
ІСТОРІЯ НАУКИ
}

\author{
DOI: 10.32703/2415-7422-2018-8-2(13)-425-435
}

\section{УДК 63:001.891:632.112(292.486)(091/092)}

\author{
Воловодовська Вікторія Олександрівна \\ Національна наукова сільськогосподарська бібліотека \\ Національної академії аграрних наук України \\ вул. Героїв Оборони, 10, м. Київ, Україна, 03127 \\ e-mail: Volovodovskavo@ukr.net \\ https://orcid.org/0000-0002-2795-5574
}

\section{Харківський період діяльності професора П.Ф. Тушкана (1934-1942 рр.)}

Анотація. Розкрито життєвий шлях і творчі звитяги П.Ф. Тушкана. Проаналізовано його напраџювання на ниві становлення й розвитку аграрної науки в Украӥні. Серед них особливе місие посідає Харківський період впродовж якого учений працював старшим науковим співробітником Всеукраїнської академії сільськогосподарських наук (19341936 рр.), 1936 р. - прийнятий позаштатно до Українського науково-дослідного інституту соціалістичного землеробства, де прачював над науковим завданням «Посухи $і$ їх вплив на врожаї УРСР». Він стверджував, що приймати заходи по боротьбі з посухами потрібно не тодi, коли вона настала, а завчасно. За результатами досліджень П.Ф. Тушкан формує видання, яке за рекомендаціями Інституту та НКЗС УРСР було вирішено опублікувати після отримання рецензій фахівиів. Після їх отримання вченим було доопраџьовано книгу, однак Інститут був не в змозі ї̈ надрукувати. Звернення Павла Федоровича до президента ВАСХНІЛ, а згодом 24 травня 1940 р. до Президії ВУАН з метою посприяти отриманню рецензї̈ на книгу та ї̈ друку не увінчалися успіхом. Майже через рік, 20 серпня 1941 р. вчений звернувся до керівниитва Украӥнського науково-дослідного інституту сочіалістичного землеробства з проханням опублікувати його статтю "Сільськогосподарські посухи $i$ їх вивчення» та одночасно написав листа академіку АН УРСР та ВАСГНІЛ О.Н. Соколовському щзодо сприяння в просуванні у друці своєї багаторічної наукової роботи з вивчення посухи. О.Н. Соколовський після ознайомлення з виданням надав заключення П.Ф. Тушкану в якому він відмітив важливість та корисність опублікування книги для фахівиів. У жовтні 1941 р. вчений звернувся до Українського науково-дослідного інституту сочіалістичного землеробства з бажанням передати матеріали своєї роботи з дослідження посухи в УРСР, але внаслідок вторгнення німецьких військ до Харкова, Інститут не встиг евакуюватися $і$ їхня доля залишилася не відома. Взимку 1942 р. здоров'я Павла Федоровича значно погіршилося внаслідок виснаження від недоїдання, щзо в свою чергу спровокувало параліч серия і вчений помер. Тепер, колись піонерське відкриття світового виміру зроблене П.Ф. Тушканом стосовно того, щчо посухи в степах України мають періодичний характер та пов'язані з сонячною активністю, стало аксіомою, але його авторство належить вже іншим.

Ключові слова: П.Ф. Тушкан; посухи; дослідна справа; видання

\section{Вступ}

Україна має надзвичайно сприятливі природно-соціальні умови для розвитку сільського господарства, зокрема - помірний клімат, родючі грунти, 
великі площі орних земель, хліборобські традиції. Вона справедливо вважається житницею світового виміру. Водночас в окремі роки Україні притаманні посухи, які негативно впливають на агровиробництво, вносячи істотні корективи в агростатистику. Загалом посухи належать до небезпечних природних явищ, які супроводжуються підвищенням температури повітря i грунту, сильною спекою, призводячи до зневоднення територій, пригнічення $\mathrm{i}$ навіть загибелі сільгоспкультур на великих площах, вигорання травостоїв, браку корму та масового скорочення кількості худоби, вітрової ерозії, зниження рівня грунтових вод, висихання озер, водойм і боліт, міління річок, порушення роботи гідроелектростанцій, систем водопостачання та промислових підприємств, лісових пожеж, загорання торфовищ, погіршення стану здоров'я населення і навіть до людських жертв. Особливо потерпає від посух агросектор, i в першу чергу - зернове господарство. За останні 120 років в Україні зафіксовано понад 70 посух. Особливо жорсткими і катастрофічними за наслідками були посухи 1891, 1921 і 1946 року, які призвели до загибелі урожаю, голоду i людських жертв. Тому стаття $є$ актуальною, оскільки комплексне дослідження наукової спадщини професора П.Ф. Тушкана щодо питання посухи та іiі впливу на врожай сільськогосподарських культур доповнює загальну історію науки і техніки України в цілому та агрономії зокрема.

\section{Методи дослідження}

Методологічною основою дослідження $\epsilon$ принципи історичної достовірності, об'єктивності, системності та комплексності. Використано загальнонаукові (аналіз, синтез, типологізація), міждисциплінарні (структурносистемний) та власне історичні (проблемно-хронологічний, порівняльноісторичний та ін.) методи.

\section{Результати та Обговорення}

Павло Федорович Тушкан народився 29 червня 1867 р. в с. Богучари Залімановської волості Богучарського повіту Воронезької губернії в багатодітній родині державних селян. 3 малечку батьки прищепили Павлу любов до нелегкої праці хлібороба, рідного краю, мови та традицій українського народу, навчаючи кмітливості та працелюбності. Біографія відомого вченого та педагога $є$ досить типовою для представника інтелігенції, яка впродовж останньої чверті XIX ст., завдячуючи особистому інтелектуальному таланту, спромоглася досягти вагомих соціальних позицій у суспільстві даної доби.

Юнак, як і більшість вихідців із незаможних селянських родин того часу, розпочав свій освітній шлях зі вступу до двокласного міністерського училища, скориставшись можливостями, які надавала дітям селян реформа початкової освіти. Навчання у міністерській школі виявило в обдарованого школяра неординарні інтелектуальні здібності та неабияку схильність до навчання. 
Шкільна наука легко давалась талановитому хлопцю, відкриваючи для нього привабливі життєві обрії та професійні перспективи.

Після закінчення міністерської школи здібний юнак, вирішив продовжити свою освіту в Воронезькому реальному училищі [1, с. 453]. Навчання в ньому тривало 6 років. Після певних вагань та розмірковувань Павло Тушкан вирішив вступати до Петрово-Розумовської сільськогосподарської академії - вищого закладу аграрної освіти Російської імперії (м. Москва), де в той час плідно займалися науково-дослідницькою діяльністю та викладали всесвітньовідомі вчені вітчизняної аграрної науки: К.А. Тимірязев, Г.Г. Густавсон, І.А. Стебут, А.Ф. Фортунатов. Наступні кілька років життя П. Тушкана будуть тісно пов'язані 3 дослідницькими установами Полтавського товариства сільського господарства, яке було засноване 1865 р. за ініціативи дворянства Полтавської губернії та особисто князя С.В. Кочубея - одного 3 найбільш заможних землевласників регіону [2, с. 42; 3, с. 7]. У 1895 р. після закінчення вишу він приймає пропозицію Товариства й обіймає посаду помічника директора Полтавського дослідного поля. Згодом, оцінивши його здібності як талановитого організатора та професіонала-землероба, П. Тушкану було запропоновано посаду вченого секретаря Полтавського сільськогосподарського товариства [4, с. 554].

Плідна адміністративна та дослідницька діяльність Павла Тушкана в Полтавському сільськогосподарському товаристві привернула до нього увагу представників катеринославських земських установ, які в даний період переймалися активним пошуком кандидатури на посаду директора початкової сільськогосподарської школи. У 1899 р. П.Ф. Тушкан обійняв посаду директора Верхньодніпровської нижчої сільськогосподарської школи Катеринославського губернського земства.

П.Ф. Тушкан був серед активних учасників знакового Першого Всеукраїнського агрономічно-економічного з'їзду, скликаного 22-26 жовтня 1917 p. у Києві. За доносом зі звинуваченнями у більшовизмі його заарештували гайдамаки і майже два місяці тримали за гратами і невдовзі звільнили. Як знаному професіоналу йому запропонували високу посаду в головному аграрному відомстві. Але він відмовився. Після цього П.Ф. Тушкан очолив культурно-просвітницький відділ Центрального сільськогосподарського кооперативного союзу («Централ»).

У 1918 р. світ побачила розгорнута остаточна програма курсів з кооперації в сільському господарстві за авторством П.Ф. Тушкана $[5$, с. $117-120 ; 6$, с. 3841]. Вона містила 15-годинний цикл «Товарознавство сільськогосподарський продуктів та матеріалів» із 12-годинними відповідними екскурсіями. Останні П.Ф. Тушкан планував проводити при кабінеті товарознавства Київського коопераційного інститут. Однак не склалося. Він приймає рішення виїхати 3 Києва. Щодо його родини, то, судячи з вихідних даних листів з грошовими переказами, вона $з 1917$ р. мешкала у м. Судак на південному узбережжі Криму на придбаній у кредит у 1916 р. дачі з виноградною ділянкою. 3 лютого 1919 р. 
до 15 серпня 1923 р. П.Ф. Тушкан працював учителем у Судакській трудовій школі II ступеня.

У листопаді 1920 р. після встановлення на Кримському півострові радянської влади П.Ф. Тушкан повертається до Харкова і активно долучається до процесу організаційних змін галузевого науково-освітнього процесу через систему Наркомзему УСРР. Спочатку працював завідувачем підсекції шкільної сільськогосподарської освіти, а з середини 1923 р. - головою Київської філії Сільськогосподарського наукового комітету України. На черговому Пленумі 29 грудня 1923 р. було прийнято остаточне рішення про переведення СГНКУ до Харкова від січня 1924 p. і його організаційну побудову. Згідно 3 нею П.Ф. Тушкан обраний заступником голови комітету В.I. Ковалевського. На тому ж засіданні стає ще дійсним членом i головою секції сільськогосподарської освіти та популяризації [7, с. 78], хоча ці обов'язки (функції) П.Ф. Тушкан розпочав здійснювати дещо раніше. Від 27 лютого 1924 р. він стає членом президії економічної секції СГНКУ і одним із розробників нової програми іiі діяльності. На початку квітня 1924 р. і до 21 червня 1924 р. П.Ф. Тушкан взагалі очолив СГНКУ, який небезпідставно вважається однією з предтеч сучасної Національної академії аграрних наук України. Відтоді П.Ф. Тушкан став керівником рільничої секції СГНКУ. Але вже в 1927 р. розпочалася реорганізація СГНКУ. Нововведення спонукали П.Ф. Тушкана $з$ липня 1927 р. змінити місце роботи і переїхати до Полтави. Всі подальші звитяги на освітній ниві П.Ф. Тушкан цілком реалізував у Полтавському сільськогосподарському політехнікумі (нині - Полтавська державна аграрна академія). П.Ф. Тушкан розпочинає системну підготовку свого, мабуть, найбільш фундаментального дослідження під умовною назвою «Погода і врожаї», де вивчає дію посухи в Україні, особливо на тлі загибелі озимини в 1928 р. Враховуючи надзвичайну цінність отриманих наукових результатів для практики в системі продовольчої безпеки, вченого повертають до Харкова.

Протягом 1934-1936 pр. П.Ф. Тушкан обіймає посаду старшого наукового співробітника з агротехніки та сівозмін тваринницьких районів і кормових культур сектору агротехніки та сівозмін Всеукраїнської академії сільськогосподарських наук. Створена Постановою РНК УСРР 22 травня 1931 р. , «... щоб пристосувати всю науково-дослідну роботу на Україні в галузі сільського господарства до справи піднесення та соціальної реконструкції сільського господарства ...» [8, с. 389], вона досить швидко стала заручницею політичного тиску з боку влади. Особливо він посилився після прийняття Постанови РНК УСРР та ЦК КП(б) України «Про роботу Всеукраїнської академії сільськогосподарських наук у справі підвищення врожайності» від 9 серпня 1933 р. У ній не лише звинуватили ВУАСГН у «... відсутності класової пильності ...», «... відсутності боротьби проти буржуазних поглядів в сільськогосподарській науці і шкідництві...», «... засміченості складу інститутів класово-ворожими петлюрівськими контрреволюційними 
елементами...», а й «... відриві наукової роботи від обслуговування великого соціалістичного сільського господарства...» через підтримку «... невірних і по суті шкідливих теорій (мілка оранка, питання встановлення міжрядь» $[9$, с. 159162]. Як наслідок, практично вся Президія ВУАСГН, за винятком президента академії ВУАН О.Н. Соколовського, спочатку була звільнена, а потім заарештована. Теж саме відбулося і на рівні окремих дослідницьких інституцій.

Проте, вже з 1 лютого 1934 р. П.Ф. Тушкан став до роботи після суттєвої «чистки» апарату ВУАСГН за наслідками посухи 1932-1933 рр., що призвела до голодомору $[10$, с. 26-29]. 3 метою наукового вивчення посухи рішенням Президії ВУАСГН створено спеціальну групу в складі професорів В.Г. Ротмістрова та П.Ф. Тушкана. Вона розробила програму досліджень, розраховану на п'ять років. Ї̈̈ підгрунтям стали звіти діючих дослідних станцій щодо питань збереження вологи та метеоспостережень. На їх основі П.Ф. Тушкан складав відповідні діаграми i таблиці. Його знання стали надзвичайно затребуваними у світлі розгортання так званої колгоспної дослідної справи або масового дослідництва в колгоспах [11, с. 21-33]. Під науковим керівництвом старшого наукового співробітника П.Ф. Тушкана здійснювалося виконання прийнятого ще в 1932 p. IX народногосподарського завдання «Зведеного проблемно-тематичного плану науково-дослідної роботи Всеукраїнської академії сільськогосподарських наук», а саме: «Забезпечення тваринництва кормовою базою». На його виконання передбачалося вирішення шести проблемних завдань: 1) Кормові ресурси та поширення кормових площ у районах; 2) Порайонний добір кормових культур і поживні та поукісні посіви; 3) Природні займища як кормові площі та іх використання; 4) Раціональне використання природних та штучних пасовиськ i підвищення їx продуктивності; 5) Підвищення поживності кормів селекцією та агротехнічними заходами; 6) Сівозміни тваринницьких господарств. Після ліквідації ВУАСГН наказом НКЗС УРСР №167 від 31 березня 1935 р. [12], за рішенням відповідної комісії П.Ф. Тушкан з 19 квітня 1935 р. відряджений до Українського науково-дослідного інституту тваринництва. Внаслідок погіршення стану здоров'я 15 травня 1936 р. він звільняється з займаної посади і виходить на пенсію.

Зрозуміло, що пенсії для повноцінного життя не вистачало. Тому П.Ф. Тушкан наказом №696 від 10 вересня 1936 р. був прийнятий понадштатно до Українського науково-дослідного інституту соціалістичного землеробства (нині - ННЦ «Інститут землеробства НААН») для виконання наукової роботи «Посухи і їх вплив на врожаї в УРСР». Уже 16-17 січня 1938 р. про іiі результати він доповів на засіданні відділу агротехніки Українського науководослідного інституту соціалістичного землеробства. За рекомендаціями Інституту і НКЗС УРСР результати досліджень П.Ф. Тушкана було вирішено опублікувати після отримання рецензій відповідних фахівців. 3 цією метою брошура 1 жовтня 1938 р. була направлена до ВАСГНІЛ. Звідти ії передали до відділення метеорології Всесоюзного науково-дослідного інституту 
рослинництва. Незважаючи на вісім зауважень та твердження, що «... підхід автора до вирішення завдань без сумніву вірний, але все таки повторює вже встановлені істини...», рецензенти, тим не менше, роблять висновки про її «... безумовну корисність ...» і доцільність видання після доопрацювання «... для пропаганди правильних понять про явище посухи».

Після цього П.Ф. Тушкан доопрацьовує книгу і 14 березня 1940 р. відсилає ii, як попереднє повідомлення, президенту ВАСГНІЛ академіку Т.Д. Лисенку, сподіваючись прискорити іï друк без додаткових рецензій та заключень. Однак цього не трапилося. Для початку брошуру відправили на рецензування до Інституту зернового господарства Південного Сходу СРСР (м. Саратов). У липні 1940 р. Павло Федорович отримує від секретаря Президії ВАСГНІЛ Е. Крутікова лист з повідомленням, що книга прорецензована, але інститут не в змозі їі надрукувати.

За таких обставин П.Ф. Тушкан новим листом прохає президента ВАСГНІЛ посприяти отримати рецензію на книгу і допомогти в її друці. Однак відповіді не надійшло. Розуміючи, що час безповоротно спливає, Павло Федорович із наявними висновками фахівців листом від 24 травня 1940 р. звертається з тим же проханням тепер уже до Президії ВУАН. Вона, не мудруючи, надсилає рукопис на заключення до Інституту ботаніки ВУАН. Листом №148 від 7 червня 1941 р. директор Інституту ботаніки ВУАН академік АН УРСР М.М.Гришко запросив П.Ф. Тушкана на нараду для обговорення роботи «Посухи i їх дослідження». Головував академік АН УРСР М.Г. Холодний. Застосовані архівні джерела, на переконання більшості присутніх, не були достатньо репрезентаційними для запропонованих автором загальних висновків. Тому фахова спільнота вважала, що вони можуть ввести спеціалістів в оману, тим більше, що автор дослідження на врахував дрібні опади.

У нащадків П.Ф. Тушкана зберігся лист М.Г. Холодного до М.М. Гришка, в якому він наголошує, що Павло Федорович у своїй роботі «... не розглядає питання фізіології рослин і розглядає явище посухи під таким кутом погляду, що важко дати необхідний висновок «... після прочитання книги». Він пропонує передати книгу П.Ф. Тушкана на розгляд «... Любименку, Кузьменку і Власюку...», щоб вони спільно надали рецензію. Як вдалося встановити, вони ii надали із загальним висновком: «Після відповідних виправлень і переробки робота заслуговує видання у вигляді окремої брошури, коротке i доступне викладення головних положень і висновків 3 відповідним обгрунтуванням, можна було б дати у вигляді популярної журнальної статті або більш зжатої газетної статті». Тим самим, підтвердили думку М.Г. Холодного, що книга «...не позбавлена інтересу...»

Після таких всебічних «критик» на всіх рівнях, у когось, можливо б, опустилися вже руки, але це не про П.Ф. Тушкана. Вчений продовжує свої дослідження, відкидаючи всі негаразди, що накопичувалися у житті вченого останнім часом, починаючи зі смерті дружини Юлії Платонівни 27 червня 
1938 р. Він важко пережив цю втрату і залишився фактично сам у Харківській квартирі. Суттєво погіршився стан В.Ф. Тушкана. Найбільшою втіхою для вченого було листування з дітьми. Особливо пишався здобутками сина Юрія. Клопотав про збільшення розміру пенсії. Рішенням управління Державного забезпечення Наркомсоцбез УРСР відповідно до ст. 18 «Положення про пенсійне забезпечення наукових установ від 09.04.1938 р.» з 1 серпня 1938 р. йому збільшено пенсію до 350 крб.

Війна внесла чергові корективи в життя вченого. Фронт стрімко просувався в бік Харкова. П.Ф. Тушкан 20 серпня 1941 р. звернувся до директора Українського науково-дослідного інституту соціалістичного землеробства 3 проханням опублікувати його статтю «Сільськогосподарські посухи і їх вивчення при першій можливості. Паралельно пише листа академіку АН УРСР та ВАСГНІЛ О.Н. Соколовському, в якому прохає посприяти у друці результатів багаторічної роботи з вивчення посухи. Академік своїм підписом 20 серпня 1941 р. підтвердив прийняття звернення, а 24 серпня 1941 р. надав автору коротке заключення про статтю. У ній він підсумував, що вважає за корисне опублікування роботи В.Ф. Тушкана для привернення уваги фахівців.

Наближення фронту до Харкова змусило вченого 7 жовтня $1941 \mathrm{p}$. звернутися до Українського науково-дослідного інституту соціалістичного землеробства з бажанням передати їм матеріали по дослідженню посух в УРСР. Оскільки останній не встиг евакуюватися, ймовірно, передані вченим матеріали залишилися в окупованому німцями Харкові і доля їх є не відомою.

3 початку вторгнення німецьких загарбників П.Ф. Тушкан робить всілякі спроби виїхати з Харкова. Однак не склалося з багатьох причин, передусім, пов'язаних зі здоров'ям. Радянські війська за наказом Верховного головнокомандування Збройних Сил СРСР 24 жовтня 1941 р. залишили Харків [13, с. 211-258]. Розпочалася німецько-фашистська окупація міста. Вже наступного дня військова комендатура міста оголосила, що всі промислові підприємства, наукові установи, освітні заклади та культурні центри $€$ власністю «великої Німеччини».

Вчений помер 22 лютого 1942 р. о 7 годині вечора від виснаження i, у зв'язку з цим, паралічем серця, обумовленим систематичним напівголодним станом організму протягом останніх $1 / 2$ років і повним голодуванням останніх місяців.

На початку 70-х років минулого століття заради відновлення справедливості учні П.Ф. Тушкана зробили спробу віднайти сліди рукопису «Сільськогосподарські посухи та їх вивчення в Україні». Так, М.П. Пестушко 21 квітня 1972 р. звернувся до заступника голови Комітету у справах винаходів та відкриттів при Раді Міністрів СРСР Царегородцева і направив копії рецензій та листування П.Ф. Тушкана з різними відомствами про бажання опублікувати працю усього життя. Ї̈і сутність полягала в наступному. Проаналізувавши зібрані особисто статистичні відомості кліматичних змін в Україні за 300 років, Павло Федорович висунув принципово нове визначення поняття «посухи» i 
дійшов висновку, що посухи в степах України мають періодичний характер та пов'язані з появою плям на Сонці, тобто з сонячною активністю. Він відмітив два періоди виникнення посухи: один - кожні 11 р. (велика посуха), а другий через 8 р. (часткова посуха). Гіпотеза про зв’язок посухи з плямами на Сонці на час іiі оприлюднення виявилася занадто революційною. Класичні вчені іï не сприйняли через недосконалу методику визначення i недостатню кількість експериментальних досліджень тощо. Свої висновки Павло Федорович удосконалював до кінця свого життя, постійно консультуючись 3 фахівцями [14, с. 68-72].

\section{Висновки}

Таким чином, до наукового обігу повернено бачення посухи авторитетним українським ученим, результати досліджень якого не були своєчасно оприлюднені. Хоча, при цьому вони мають важливе практичне значення для цивілізованого світу. Тим більше, сьогодні не лише Україна, а й Європа і світ потерпають від проявів посухи.

\section{Джерела та література}

1. Чабан М. Діячі січеславської «Просвіти» (1905-1921): біобібліографічний словник. Дніпропетровськ, 2002. 535 с

2. Лисенко М.С. Полтавське товариство сільського господарства: історія і досвід (до 150 річниці). 2015. № 47. С. 41-62.

3. Вергунов В.А. Полтавському товариству сільського господарства - 150 років: віхи видатних діянь на благо України. Вінниця, 2015. 96 с.

4. Тушкан П. Годовой отчет по Верхнеднепровской Екатеринославского губернского земства нижшей сельскохозяйственной школе 1-го разряда, за 1899/1900 учебный года. Приложения к постановлениям Екатеринославского губернского земского собрания XXXVI очередной 1901 года сессии с 1-го по 14 декабря включительно. Екатеринослав: Типография губернского земства, 1902. С. 552-574.

5. Берестень Ю.В., Мороз B.I. Павло Федорович Тушкан - фундатор початкової та середньої сільськогосподарської освіти Придніпров'я початку ХХ століття. Проблеми політичної історії України. 2018 р. Вип. 13. С. 106-130.

6. Тушкан П. Програми курсів по кооперації в сільському господарстві. Сільський госnодар. 1918. Ч. 9 (1 листоп.). С. 38-41.

7. Personalia. Обрання на дійсних членів СГНКУ. Вісник сільськогосподарської науки. 1923. N 8-12 (серпень-грудень). С. 308.

8. Постанова РНК УСРР «Про організацію Всеукраїнської академії сільськогосподраських наук. Збірник документів та розпоряджень Робітничо-селянського Уряду України. 1931. №18, 4 черв. С. 389. Арк. 154.

9. Постанова РНК УСРР та ЦК КП(б) України «Про роботу Всеукраїнської академії сільськогосподарських наук у справі підвищення врожайності» від 9 серпня 1933 р. Український науково-дослідний інститут економіки й організації сільського господарства (1928-1937 рр.) / уклад.: В.А. Вергунов, Г.О. Глазунов, І.О. Зосімов; під заг. ред. В.А. Вергунова. Вінниця, 2015. С. 159-162.

10. Василенко В. Голодомор 1932-1933 років в Україні як злочин геноциду. Правова оцінка. Київ, 2009. 47 с. 
11. Вергунов В.А. Колгоспна дослідна справа. Історія украйнської науки на межі тисячоліть: зб. наук. пр. / відп. ред. О.Я. Пилипчук. 2007. Вип. 32. С. 21-33.

12. ЦДАВО України. Ф.1055. Оп. 2. Спр. 57. Арк. 71.

13. Бакіров В.С., Духопельников В.М., Зайцев В.П. Харківський національний університет ім. В.Н. Каразіна за 200 років. Харків, 2004. С. 415.

14. Вергунов В.А. Професор П.Ф. Тушкан (1867-1942) - учений, освітянин, громадський і політичний діяч. Полтава, 2018. 112 с.

\title{
Воловодовская Виктория Александровна
}

Национальная научная сельскохозяйственная библиотека

Национальной академии аграрных наук Украины

ул. Героев Обороны, 10, г. Киев, Украина, 03127

\section{Харьковский период деятельности профессора П.Ф. Тушкана (1934-1942 гг.)}

\begin{abstract}
Аннотация. Раскрыто жизненный путь и творческие победы П.Ф. Тушкана. Проанализированы его наработки на ниве становления и развития аграрной науки в Украине. Среди них особое место занимает Харьковский период на протяжении которого ученьй работал старшим научным сотрудником Всеукраинской академии сельскохозяйственных наук (1934-1936 г2.), 1936 - принят внештатно в Украинский научноисследовательский институт сочиалистического земледелия, где работал над научным заданием «Засухи и их влияние на урожай УССР». Он утверждал, что принимать меры по борьбе с засухами нужно не тогда, когда она наступила, а заранее. По результатам исследований П.Ф. Тушкан формирует издание, по рекомендациям Института и НКЗД УССР было решено его опубликовать после получения рецензий специалистов. После их получения ученым было доработано книгу, однако Институт был не в состоянии ее напечатать. Обращение Павла Федоровича к президенту ВАСХНИЛ, а затем 24 мая 19402. в Президиум ВУАН с иелью поспособствовать в получении рецензии на книгу и ее печати не увенчалось успехом. Почти через год, 20 августа 1941 г. ученый обратился к руководству Украинского научно-исследовательского института соииалистического земледелия $c$ просьбой опубликовать его статью «Сельскохозяйственные засухи и их изучение» $u$ одновременно написал письмо академику АН УССР и ВАСХНИЛ А.Н. Соколовскому по содействию в продвижении в печати своей многолетней научной работь по изучению засухи. А.Н. Соколовский после ознакомления с изданием предоставил заключение П.Ф. Тушкану в котором он отметил важность и полезность опубликования книги для спечиалистов. В октябре 1941 г. ученый обратился $\kappa$ Украинскому научноисследовательскому институту сочиалистического земледелия с желанием передать материаль своей работы по исследованию засухи в УССР, но в результате вторжения немецких войск в Харьков, Институт не успел эвакуироваться и их судьба осталась неизвестна. Здоровье Павла Федоровича значительно ухудшилось вследствие истошения от недоедания, что в свою очередь спровоцировало паралич сердияа и зимой 1942 г. ученьии умер. Теперь, когда-то пионерское открытие мирового масштаба сделано П.Ф. Тушканом о том, что засухи в степях Украины имеют периодический характер и связаны с солнечной активностью, стало аксиомой, но его авторство принадлежит уже другим.
\end{abstract}

Ключевые слова: П.Ф. Тушкан; засухи; исследовательское дело; издание 
Volovodovska Victoria

National Scientific Agricultural Library of National Academy of Agrarian Sciences of Ukraine 10, Geroiv Oborony St., Kyiv, Ukraine, 03127

\title{
Kharkiv period of activity professor P.F. Tushkan (1934-1942)
}

\begin{abstract}
The way of life and creative victories of P.F. Tushkan, his achievements in the field of formation and development of agrarian science in Ukraine are analyzed. Among them, the Kharkiv period occupies a special place during which the scientist worked as a senior researcher of the All-Ukrainian Academy of Agricultural Sciences (1934-1936), and in 1936 he was freelance to the Ukrainian Research Institute of Socialist Agriculture, where he worked on the scientific task "Drought and their impact on the crops of the Ukrainian SSR». He argued that taking measures to deal with drought is not necessary when it came, but in advance. According to research results P.F. Tushkan forms a publication, which, based on the recommendations of the Institute and the PCCLA of the Ukrainian SSR, was decided to publish after receiving expert reviews. After their getting, the book was revised, but the Institute was not able to print it. The treatment of Pavlo Fedorovych to the president of VASKHNIL, and later on May 24, 1940, to the Presidium of VUAN, in order to facilitate a review of the book and its publication, were not successful. Almost a year later, on August 20, 1941, the scientist appealed to the leadership of the Ukrainian Research Institute for Socialist Agriculture, with a request to publish his article "Agricultural drought and their study" and at the same time wrote a letter to the academician of the Academy of Sciences of the USSR and VASGNIL O.N. Sokolovskyi concerning the promotion of his long-term research work on the study of drought in the press. After studying the publication, Sokolovskyi gave a conclusion to P.F. Tushkan in which he noticed the importance and usefulness of publishing a book for specialists. In October 1941, the scientist appealed to the Ukrainian Research Institute of Socialist Agriculture with a desire to transfer the materials of his work on the study of droughts in the Ukrainian SSR, but as a result of the invasion of the German troops to Kharkov, the Institute did not have time to evacuate and their fate remained unknown. The health of Pavlo Fedorovich has deteriorated significantly owing to the exhaustion of malnutrition, which in turn provoked paralysis of the heart and in the winter of 1942 the scientist died. Now, once the pioneering discovery of the world dimension is made by P.F. Tushkan, in connection with the fact that droughts in the steppes of Ukraine are of a periodic nature and associated with solar activity, has become axiomatic, but its authorship belongs to others.
\end{abstract}

Keywords: P.F. Tushkan; drought; research; publication

\section{References}

1. Chaban M. (2002) Diiachi sicheslavskoi «Prosvity» (1905-1921) [Figures of Sichslav's «Enlightenment» (1905-1921)]. Dnipropetrovsk [in Ukrainian].

2. Lysenko M.S. (2015). Poltavske tovarystvo silskoho hospodarstva: istoriia i dosvid (do 150 richnytsi) [Poltava Society of Agriculture: History and Experience (up to 150 anniversaries)]. [in Ukrainian].

3. Verhunov V.A. (2015). Poltavskomu tovarystvu silskoho hospodarstva - 150 rokiv: vikhy vydatnykh diian na blaho Ukrainy [Poltava Association of Agriculture - 150 years: milestones of outstanding actions for the benefit of Ukraine]. Vinnytsia [in Ukrainian].

4. Tushkan P. (1902). Godovoy otchet po Verhnedneprovskoy Ekaterinoslavskogo gubernskogo zemstva nizhshey selskohozyaystvennoy shkole 1-go razryada, za 1899/1900 uchebnyiy goda [Annual report on the Verkhneidneprovsk Yekaterinoslav provincial zemstvos lower agricultural school of the 1st level, for 1899/1900 academic year]. Prilozheniya $k$ postanovleniyam Ekaterinoslavskogo gubernskogo zemskogo sobraniya HHHVI ocherednoy 1901 
goda sessii s 1-go po 14 dekabrya vklyuchitelno. Ekaterinoslav: Tipografiya gubernskogo zemstva in Russian].

5. Beresten Yu.V., Moroz V.I. (2018). Pavlo Fedorovych Tushkan - fundator pochatkovoi ta serednoi silskohospodarskoi osvity Prydniprovia pochatku XX stolittia [Pavel Fedorovich Tushkan is the founder of primary and secondary agricultural education in the Dnieper region of the early twentieth century]. Problemy politychnoi istorii Ukrainy [in Ukrainian].

6. Tushkan P. (1918). Prohramy kursiv po kooperatsii v silskomu hospodarstvi [Programs of courses in agricultural co-operation]. Silskyi hospodar [in Ukrainian].

7. Personalia. Obrannia na diisnykh chleniv SHNKU [Election to active members of SNCU]. Visnyk silskohospodarskoi nauky. 1923. № 8-12 (serpen-hruden). S. 308 [in Ukrainian].

8. Postanova RNK USRR «Pro orhanizatsiiu Vseukrainskoi akademii silskohospodraskykh nauk» (1931). [Resolution of the SNK of the Ukrainian SSR «On the organization of the AllUkrainian Academy of Agricultural Sciences»]. [in Ukrainian].

9. Postanova RNK USRR ta TsK KP(b) Ukrainy «Pro robotu Vseukrainskoi akademii silskohospodarskykh nauk u spravi pidvyshchennia vrozhainosti» vid 9 serpnia 1933 r. Ukrainskyi naukovo-doslidnyi instytut ekonomiky y orhanizatsii silskoho hospodarstva (1928-1937 rr.) (2015). [Resolution of the RNK of the Ukrainian SSR and the Central Committee of the CPU (b) of Ukraine «On the work of the All-Ukrainian Academy of Agricultural Sciences in raising productivity» of August 9, 1933, the Ukrainian Research Institute of Economics and Agriculture (1928-1937 biennium)]. [in Ukrainian].

10. Vasylenko V. (2009). Holodomor 1932-1933 rokiv v Ukraini yak zlochyn henotsydu. Pravova otsinka [Holodomor of 1932-1933 in Ukraine as a crime of genocide. Legal assessment]. Kyiv [in Ukrainian].

11. Verhunov V.A. (2007). Kolhospna doslidna sprava [Farns is an experimental business]. Istoria ukrainskoi nauky na mezhi tysiacholit: zb. nauk. pr. / vidp. red. O.Ia. Pylypchuk [in Ukrainian].

12. TsDAVO Ukrainy [TsDIAO of Ukraine]. F. 1055. Op. 2. Spr. 57. Ark. 71 [in Ukrainian].

13. Bakirov V.S., Dukhopelnykov V.M., Zaitsev V.P. (2004). Kharkivskyi natsionalnyi universytet im. V.N. Karazina za 200 rokiv [Kharkiv National University named after. VN Karazin for 200 years]. Kharkiv [in Ukrainian].

14. Verhunov V.A. (2018). Profesor P.F. Tushkan (1867-1942) - uchenyi, osvitianyn, hromadskyi i politychnyi diiach [Professor P.F. Tushkan (1867-1942) - a scientist, an educator, a public and political figure]. Poltava [in Ukrainian].

Received 20.11.2018

Received in revised form 01.12.2018

Accepted 03.12.2018 